California GAMA Special Study: Examination of Water Quality of Tritium-Dead Drinking Water Wells

A. Visser, J. E. Moran, M. J. Singleton, D. J. Hillegonds, K. Belitz, J. Kulongoski, M. S. Fram, B. K. Esser

May 23, 2012 
This document was prepared as an account of work sponsored by an agency of the United States government. Neither the United States government nor Lawrence Livermore National Security, LLC, nor any of their employees makes any warranty, expressed or implied, or assumes any legal liability or responsibility for the accuracy, completeness, or usefulness of any information, apparatus, product, or process disclosed, or represents that its use would not infringe privately owned rights. Reference herein to any specific commercial product, process, or service by trade name, trademark, manufacturer, or otherwise does not necessarily constitute or imply its endorsement, recommendation, or favoring by the United States government or Lawrence Livermore National Security, LLC. The views and opinions of authors expressed herein do not necessarily state or reflect those of the United States government or Lawrence Livermore National Security, LLC, and shall not be used for advertising or product endorsement purposes.

This work performed under the auspices of the U.S. Department of Energy by Lawrence Livermore National Laboratory under Contract DE-AC52-07NA27344. 


\title{
Water Quality of "Tritium-Dead" Drinking Water Wells in California
}

\author{
Ate Visser ${ }^{1 *}$, Jean E Moran ${ }^{2}$, Michael J Singleton ${ }^{1}$, Darren Hillegonds ${ }^{1}$, Ken Belitz ${ }^{3}$, Justin Kulongoski ${ }^{3}$, \\ Miranda S Fram ${ }^{3}$ and Bradley K Esser ${ }^{1}$ \\ 1: Chemical Sciences Division, LLNL, Livermore, CA; visser3@1lnl.gov \\ 2: Department of Earth \& Environmental Sciences, California State University, East Bay, Hayward, CA \\ 3: USGS California Water Science Center, San Diego, CA \\ *: presenting author
}

Understanding ambient levels of regulated constituents with predominantly natural sources, such as arsenic and uranium, or with both natural and anthropogenic sources, such as nitrate, salinity and perchlorate, is important for attributing source, assessing susceptibility, and for groundwater basin management. For California, the data acquired by the GAMA Priority Basin projects (http://www.swrcb.ca.gov/gama/; Belitz, 2003, USGS WRIR 03-4166) provides a unique opportunity to assess pre-development groundwater quality.

We selected GAMA Priority Basin samples with tritium concentration of less than $1 \mathrm{pCi} / \mathrm{L}$. Given the historical levels of tritium in precipitation in the Pacific coastal region, a threshold of less than $1 \mathrm{pCi} / \mathrm{L}$ of tritium is required to ensure that less than $25 \%$ of the pumped groundwater recharged after 1950. Water quality data was analyzed for eight of the groundwater provinces delineated for the Priority Basin project.

Pre-development groundwater reflects the various hydrogeochemical settings found in California, providing natural sources of contaminants in drinking water. Nitrate is found in pre-modern groundwater, albeit infrequently, at concentrations significantly above the typical background concentrations of 9 mg/L as $\mathrm{NO}_{3}^{-}$ (Nolan, 2002, EST 36:2138) in many of the provinces studied. The lowest nitrate concentrations in tritium-dead groundwater are found in the North Coast Region province. In the Central Valley, South Coast Ranges and Basin and Range provinces, nitrate concentrations of up to $12 \mathrm{mg} / \mathrm{L}$ (as $\mathrm{NO}_{3}{ }^{-}$) were measured in tritium-dead non-anoxic (likely non-denitrifying) groundwater. This value is close to the criterion used for identifying anthropogenic nitrate of $>13 \mathrm{mg} / \mathrm{L}$ by Squillance (2002, EST 36:1923). In the Transverse and Peninsular Range, San Diego, Sierra Nevada and Desert provinces, nitrate concentrations exceeding the $13 \mathrm{mg} / \mathrm{L}$ criterion (up to $37 \mathrm{mg} / \mathrm{L}$ ) were found in a significant proportion of wells that are unlikely to be affected by anthropogenic inputs of N. These three provinces are all characterized by arid climates, where atmospherically-delivered nitrate may accumulate in the vadose zone, and be flushed into groundwater during wet periods or when irrigation water is applied. Interestingly, some of the provinces with low background concentrations, especially Central Valley and South Coast Ranges provinces, are areas strongly affected by anthropogenic $\mathrm{N}$ inputs in the last few decades because of manure from dairy operations, and fertilizer applied to row crops and orchards (e.g., Harter et al., 2012).

We conclude that the uncertainties in contaminant source attribution studies of contaminant compounds with both natural and anthropogenic sources can be reduced through a detailed aquifer-scale study of ambient levels in tritium-dead drinking water wells.

Harter, T., J. R. Lund, et al. (2012). "Addressing Nitrate in California's Drinking Water with a Focus on Tulare Lake Basin and Salinas Valley Groundwater." Report for the State Water Resources Control Board Report to the Legislature. Center for Watershed Sciences, University of California, Davis. 78 p. http://groundwaternitrate.ucdavis.edu

Dr. Ate Visser is a postdoctoral researcher at Lawrence Livermore National Laboratory since August 2010. His research focuses on transport and travel times in groundwater. His research is part of the Groundwater Ambient Monitoring and Assessment (GAMA) project sponsored by the California State Water Resources Control Board.

LLNL-ABS-558154. This work was performed under the auspices of the U.S. DOE by LLNL under Contract DE-AC52-07NA27344. 